\title{
Suppressor of Cytokine Signaling 2
}

National Cancer Institute

\section{Source}

National Cancer Institute. Suppressor of Cytokine Signaling 2. NCI Thesaurus. Code C116027.

Suppressor of cytokine signaling $2(198 \mathrm{aa}, \sim 22 \mathrm{kDa}$ ) is encoded by the human SOCS2 gene. This protein is involved in the modulation of cytokine signaling. 